\title{
Traces of Trauma with Genosociogram in a Group of Patients with Somatic Symptom Disorder
}

\author{
Bedensel Belirti Bozukluğu Olan Bir Grup Hastada \\ Genososyogram İle Travmanın İzleri
}

\author{
Şahabettin Çetin ${ }^{1}$, Gülfizar Sözeri Varma², Osman Özdel ${ }^{2}$
}

\begin{abstract}
:
The effects of traumatic life events and losses can be passed down from generation to generation through intergenerational and/or transgenerational transmission. The genosociogram is a family tree study enriched with important life events and connections. With the Genosoyogram study, it is possible to trace unresolved and incomplete traumas and ensure their completion. It is known that traumas have an important role in the etiopathogenesis of somatic symptom disorder. In this case report, it is aimed to present the results of the genosociogram study of 22 patients with somatic symptom disorder. Most of the patients had traumatic lives during childhood. It was determined that approximately one third of the patients had similar somatic symptom history, and 2 patients had anniversary reactions. It can be said that in patients with somatic symptom disorder, the genosoyogram study enables a detailed examination of the trauma and its effects, and to recognize the burdens transferred from past generations. It is also possible to see and remember positive elements such as strength, hope and commitment to life transferred from our ancestors. Studies using comprehensive and standardized measurement tools are needed on this subject.
\end{abstract}

Key Words: Somatic Symptom Disorder, Genosociogram, Trauma

\footnotetext{
${ }^{1}$ Dr., Denizli State Hospital, Denizli-Turkey, Orcid İd: https://orcid.org/ 0000-0001-8307-095X

${ }^{2}$ Prof. Dr., Pamukkale University, Faculty of Medicine, Department of Psychiatry, Denizli-Turkey, Orcid İd: https://orcid.org/ 0000-0003-4808-3274

${ }^{2}$ Prof. Dr., Pamukkale University, Faculty of Medicine, Department of Psychiatry, Denizli-Turkey, Orcid İd: https://orcid.org/ 0000-0002-6153-6744
}

Address of Correspondence/Yazışma Adresi: Pamukkale University, Faculty of Medicine, Department of Psychiatry, Denizli-Turkey, E-mail: gulfizar@gmail.com

Date of Received/Geliş Tarihi: 14.01.2021, Date of Revision/Düzeltme Tarihi: 08.02.2021, Date of Acceptance/Kabul Tarihi: 12.02.2021, Date of Online Publication/Çevirimiçi Yayın Tarihi: 01.03.2021

Citing/Referans Gösterimi: Çetin, Ş., Sözeri Varma, G., Özdel, O. (2021). Traces of Trauma with Genosociogram in a Group of Patients with Somatic Symptom Disorder, Cyprus Turkish Journal of Psychiatry \& Psychology, 3(1): 63-69

(C) 2020 The Author(s). Published by Cyprus Mental Health Institute / Cyprus Turkish Journal of Psychiatry and Psychology (www.ktppdergisi.com). This article is an open access article distributed under the terms and conditions of the Creative Commons Attribution 4.0 license which permits use, sharing, adaptation, distribution and reproduction in any medium or format, provided the original work is properly cited and is not used for commercial purposes. http://creativecommons.org/licenses/by/4.0/ 


\section{Öz:}

Travmatik yaşam olaylarının ve kayıpların etkileri kuşaklararası ve/veya kuşakaşan iletimle nesilden nesile aktarılabilmektedir. Genososyogram önemli yaşam olayları ve bağlantılarla zenginleştirilmiş bir soyağacı çalışmasıdır. Genosoyogram çalışması ile çözümlenmemiş ve tamamlanmamış travmaların izleri sürmek ve tamamlanmasını sağlamak mümkündür. Bedensel belirti bozukluğu etyopatogenezinde travmaların önemli rolü olduğu bilinmektedir. Bu olgu sunumunda, bedensel belirti bozukluğu tanılı 22 hastanın genososyogram çalışması sonuçlarının sunulması amaçlanmıştır. Hastaların çoğunluğunda çocukluk döneminde travmatik yaşantıların olduğu belirlenmiştir. Hastaların yaklaşık üçte birinde benzer bedensel belirti öyküsü, 2 hastada yıldönümü tepkileri olduğu tespit edilmiştir. Bedensel belirti bozukluğu olan hastalarda genosoyogram çalışmasının travma ve etkilerinin ayrıntılı olarak incelenmesine ve geçmiş kuşaklardan aktarılan yüklerin fark edilmesine olanak sağladığı söylenebilir. Genososyogram ile atalarımızdan aktarılan güç, umut ve yaşama bağlılık gibi olumlu öğelerin görülmesi ve hatırlanması sağlanabilmektedir. Bu konuda kapsamlı ve standardize ölçüm araçlarının kullanıldığı çalışmalara gereksinim bulunmaktadır.

Anahtar kelimeler: Bedensel Belirti Bozukluğu, Genososyogram, Travma

\section{Giriş}

Bedensel belirti bozukluğu (BBB), tıbbi olarak açıklanamayan veya açıklanabilmesine karşın önemiyle orantısız olarak içsel güç harcanan bedensel belirtilerle karakterize, kişinin sağlı̆̆ veya belirtileriyle ilgili sürekli olarak kayg1 duyduğu ve buna uygun davranışlar sergilediği ruhsal bir bozukluktur (APA, 2013). BBB'de, beden zihin etkileşimi derinden hissedilmekte olup oluşumuna biyolojik, genetik, bilişsel, psikodinamik, kültürel etmenler katkıda bulunmaktadır. Hastanın yaşadığı kültürde hastalık belirtilerinin anlamı, hastalığ 1 açıklama modelleri, kültürel değer yargıları, çocuk yetiştirme biçimleri, sözel anlatım kapasitesi, beden dilini kullanma, ruhsal savunma sistemleri, hasta rolü, çocukluk çağı travmaları ve göç gibi süreçler bedenselleştirmenin kullanılmasında ve bedensel belirti bozukluğu oluşumunda rol oynamaktadır. BBB'nin emosyonel farkındalığ 1 az olan bireylerde bir ifade biçimi olduğu ve öğrenilmiş davranış kalıplarının önemi vurgulanmakta, ayrıca geçmiş kuşaklardan aktarılan, kuşaklar arası (transgenerational) travmatik deneyimlerin bedenselleştirmeye yatkınlık oluşması açısından önemli olduğu bilinmektedir (Taycan, Sar, Celik, Erdoğan Taycan, 2014; Güleç ve ark. 2013).

Bireyin atalarının yaşadığı ve çözümlenmemiş travmaların izlerinin nesiller boyu sürülmesini ve ortaya çıkarılmasını sağlayan genososyogram çalışmalarına ilgi giderek artmaktadır. Genososyogram, önemli yaşam olayları ve bağlantılarla zenginleştirilmiş bir soyağacı çalışmasıdır. Tamamlanmamış bir iş (genellikle travmatik bir kayıp veya çözümlenmemiş bir yas) bazen birbirini tanıyan, çoğunlukla bilinçli ve sözel olarak iletilen kuşaklararası; bazen birbirinden çok uzak ve teması olmayan kuşaklar arasında kuşakaşan iletimle varlığını sürdürebilmektedir. Düşünülmeyen, konuşulmayan, sır olan, yasaklanan ve söze dökülmeyen travma izleri kuşakaşan geçişler ile nesilden nesile aktarılabilmektedir. Sözlü olmayan bu aktarımların beden diliyle olması (dil sürçmesi, hareket sürçmesi, nefes alıp verme, ateş basması, elin ayağın buz kesilmesi, uyuşma gibi) muhtemeldir. Nesiller arası aktarım birey tarafindan fark edildiğinde ve duygular söze döküldüğünde, bedensel ve psikosomatik belirtilerin ortadan kalktı̆̆ 1 ya da azaldığ 1 belirtilmektedir. Travma imgeleri belirli ve anlamlı günlerde yani aynı yaş, aynı gün, aynı ay gibi y1ldönümlerinde kazalar ve/veya hastalıklar şeklinde ortaya çıkabilmektedir (Schützenberger, 2011; Wolynn, 2016).

Psikodrama, etkileşimli bir psikodramatik gerçeklik içinde bir durumu, bir gerilimi veya bir ilişkiyi daha tatmin edici bir şekilde bitirmeyi ve etkileşimlerin kapanmasını sağlamaktadır. Psikodramatik grup terapisinin psikiyatrik hastalıkların tedavisinde yararlı olduğu bildirilmektedir (Sözeri-Varma, Karadağ, KalkanOğuzhanoğlu, Özdel, 2017; Bayraktutan, KalkanOğuzhanoğlu ve Toker Uğurlu, 2020). Psikosomatik bir hastalı olan psöriasizte psikodramatik grup terapisinin stresle başa çıkma becerilerini arttırdığ gözlenmiştir (Karadağ,Kalkan-Oğuzhanoğlu, Özdel, Ergin ve Kaçar, 2010).

BBB gelişmesinde travmatik yaşantıların önemi bilinmekle birlikte travmanın nesiller arası aktarımı konusunda bilgilerimiz sinırlıdır. Bu yazıda, 'Bedensel belirti bozukluğu ve major depresif bozukluğunda çocukluk çağı travmaları, duygu tanıma ve ifadesi ile epigenetik değişiklikler' isimli uzmanlık tezi (Çetin, 2018) kapsamında çalışmaya katılmış olan BBB hastalarından gönüllü olanlarla yapılmış genososyogram çalışması ve psikodramatik müdahale sonuçlarının sunulması amaçlanmıştır. Çalışmaya Ağustos 2016Temmuz 2017 tarihleri arasında Pamukkale Üniversitesi Tıp Fakültesi Psikiyatri polikliniğine başvuran, DSM-5 tanı ölçütlerine göre BBB tanıs1 konulan 48 hastadan 22'si katılmıştır. Çalışmayı ilgili tez asistanı ve bir psikodramatist/psikoterapist uygulamış, eğitici rolü olan bir psikodramatist/psikoterapistten süpervizyon alınmıştır. Çalışma için bir yazı tahtası, uygun büyüklükte kağıt ve renkli kalemler kullanılmıştır. Hastaların kendi yaşamları ve aile öyküleri bir soy ağacı oluşturulması şeklinde ayrıntılı olarak gözden geçirilmiştir. Soy ağacı çalışması sırasında yaşanmış travmalar, hastalıklar, bedensel belirtiler, kayıplar, yaş dönümleri ve yıl dönümü tepkileri araştırılmıştır. Atalardan aktarılan yükler ve travmatik izler nesne seçimleri ile sembolleştirilerek ve psikodramatik yöntemlerle çalışılarak değiştirilmesi ve dönüştürülmesine yardımcı olunmuştur. Önceki kuşaklardan aktarıldığı düşünülen duygusal yükler ve travma etkilerinin temsili için birer nesne seçilmesi istenmiştir. Seçilen nesnelerin neleri sembolize ettiği konuşulmuş, özellikle duygu dişavurumu desteklenerek ilgili konularda farkındalık kazanılması sağlanmıştır. Bazı hastalarda bir psikodrama tekniği olan '’boş 
sandalye" oyunuyla bugünkü hastalık belirtileri, duygusal yükler ve çözümlenmemiş travma ile ilişkilendirilen kişi ile karşılaşma sağlanmıştır. Bu yazıda genososyogram çalışmasına ait verilere odaklanılmıştır. Hastalara ve ailelere ait travmatik yaşantılar ve stresörler sunulmuş, hastaların kimliklerinin açığa çıkmaması bakımından daha fazla ayrıntı verilmemiştir.

\section{Olgu Serisi}

Çalışmaya katılan hastaların yaş ortalamaları $37.90 \pm 12.82$ yıl, eğitim yılı ortalamaları $16.00 \pm 9.19$ y1l olarak belirlendi. Olguların çoğunluğu kadın ve evliydi (her ikisi için, s:16, \%76.2). On iki hastanın (\%57.1) özgeçmişinde, 10 hastanın (\%47.6) soy geçmişinde psikiyatrik bozukluk öyküsü mevcuttu. Altı hasta fiziksel hastalığa sahipti (her birinden birer tane olmak üzere, hipertansiyon, hipotiroidi, romatoidartrit, migren, hipertiroidi, astım). Genososyogram yöntemiyle yapılan çalışmadan elde edilen bulgular ve hastanın yaşamında önemli olabileceği düşünülen olaylar Tablo 1'de özetlendi.

Tablo 1.

Travmatik yaşantılar ve tekrarlayan örüntüler

\begin{tabular}{|c|c|c|}
\hline Olgu & Travmatik yaşantılar/stresör (ler) & Aile öyküsü/ tekrarlayan örüntü \\
\hline $1, \mathrm{~K}$ & -Aldat1lma & $\begin{array}{l}\text {-Üç nesil boyunca kadınlarda aldatılma öyküsü } \\
\text {-Kadın akrabalarda benzer yaşlarda başlayan somatik } \\
\text { belirtiler, aldatılma kaygısı }\end{array}$ \\
\hline $2, \mathrm{~K}$ & $\begin{array}{l}\text {-İstenmeyen bebek } \\
\text {-Fiziksel istismar, fiziksel ve duygusal ihmal (eğitim almasının } \\
\text { engellenmesi, istemediği halde yurtdışına götürülme, baş örtüsüne } \\
\text { zorlanma ve evlendirilme) }\end{array}$ & $\begin{array}{l}\text {-Üç nesil boyunca kadınlarda fiziksel şiddete maruz kalma, } \\
\text { kardeşlerle rekabet öyküsü } \\
\text {-Ailede sözel iletişim kısıtllllığı } \\
\text {-Anne ile benzer yaşlarda başlayan somatik belirtiler }\end{array}$ \\
\hline $3, \mathrm{~K}$ & $\begin{array}{l}\text {-Boşanma } \\
\text {-Fiziksel şiddete maruz kalma }\end{array}$ & $\begin{array}{l}\text {-İki nesildir bilinen boşanma ve evlilikte fiziksel şiddete } \\
\text { maruz kalma } \\
\text {-Annede benzer somatik belirtiler }\end{array}$ \\
\hline $4, \mathrm{~K}$ & -Fiziksel şiddete maruz kalma & $\begin{array}{l}\text {-íki nesildir alkol kullanım bozukluğu ve öfke denetim } \\
\text { sorunu yaşadığ } 1 \text { ifade edilen eşler } \\
\text {-Ailede üç nesildir sesini duyuramayan, sorunları } \\
\text { görünmeyen kadınlar }\end{array}$ \\
\hline $5, \mathrm{~K}$ & -Evlilik sorunları & $\begin{array}{l}\text {-íki nesildir geniş aile sorumluluğunu tek başına üstlenme } \\
\text { rolü, evlilik sorunları, eşlerde alkol kullanım bozukluğu, } \\
\text { boşanma öyküsü } \\
\text {-Anne ve ablada benzer somatik belirtiler }\end{array}$ \\
\hline $6, \mathrm{~K}$ & $\begin{array}{l}\text {-Kendisi iki adet ölü doğum sonrası dünyaya gelen bir ikame bebek } \\
\text {-Uzun süre çocuk sahibi olamama, infertilite tedavisi sürecinde } \\
\text { başlayan somatik belirtiler }\end{array}$ & $\begin{array}{l}\text {-İki nesildir ailedeki kadınlarda çok sayıda erken bebek } \\
\text { kaybı }\end{array}$ \\
\hline $7, \mathrm{~K}$ & $\begin{array}{l}\text { Çocukluk döneminde ihmal, evlatlık verilme, maddi sorunlar, } \\
\text { çocukluk döneminde sık hastalık geçirme }\end{array}$ & 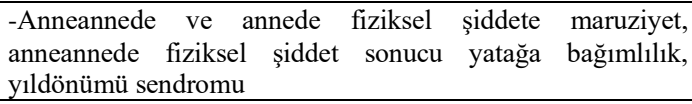 \\
\hline $8, \mathrm{~K}$ & $\begin{array}{l}\text {-İki kez evlatlık verilme, reddedilme } \\
\text {-Küçük yaşta evlilik öyküsü } \\
\text {-Eşve anneden duygusal ve fiziksel şiddet } \\
\text {-Babanın öldürülmesi }\end{array}$ & $\begin{array}{l}\text {-Aile içi iletişim sorunları } \\
\text {-Ailede yaygın şiddet öyküsü }\end{array}$ \\
\hline $9, \mathrm{E}$ & $\begin{array}{l}\text {-14 yaşında zorla evlendirilmek istenilmesi üzerine başlayan somatik } \\
\text { yakınmalar, } \\
\text {-Fiziksel ve duygusal ihmal }\end{array}$ & $\begin{array}{l}\text {-Anne ve babada erken yaşta evlilik öyküsü, } \\
\text {-Aile geleneğinde erken yaşta evlilikler ve akraba evlilikleri } \\
\text { (kendisindeki somatik belirtilerin başladığı yaş ile benzer } \\
\text { yaşlarda) } \\
\text {-Çok miktarda konuşulmayan, aile sırları }\end{array}$ \\
\hline $10, \mathrm{~K}$ & -Evlilikle birlikte başlayan somatik yakınmalar, aldatılma & $\begin{array}{l}\text {-Aile içinde sözel iletişim çok zayıf } \\
\text {-Üç kuşak boyunca geniş aileye taleplerini duyuramama } \\
\text {-Kuşaklararası devam eden evlilik sorunları }\end{array}$ \\
\hline $11, \mathrm{~K}$ & -Erken yaşta kayıplar & $\begin{array}{l}\text {-Baba tarafinda erken yaşta ölümler (kardeşler, dede, } \\
\text { babaanne...) }\end{array}$ \\
\hline $12, \mathrm{~K}$ & -Babanın hastalığı ve kaybı (bu süreçte başlayan somatik yakınmalar) & $\begin{array}{l}\text {-Üç nesildir bakım veren kadınlar ve bakıma muhtaç } \\
\text { erkekler }\end{array}$ \\
\hline $13, \mathrm{~K}$ & $\begin{array}{l}\text {-Kendi doğumu annesine adını veren büyükannesinin ölümünden kısa } \\
\text { süre sonra } \\
\text {-13 yaşında anneannenin ani ölümü } \\
\text {-23 yaşında baba kaybı } \\
\text {-Kayıplar sonrası başlayan somatik belirtiler }\end{array}$ & $\begin{array}{l}\text {-Kuşaklarca bir çok ani kayıp ve komplike yas süreçleri } \\
\text { (kayıplarla ilgili dışavurulmayan duygular) }\end{array}$ \\
\hline $14, \mathrm{E}$ & $\begin{array}{l}\text {-Çocukken boşanan ebeveynleri tarafından istenmemiş } \\
\text {-Duygusal ihmal } \\
\text {-Ebeveynleri tarafından onaylanmayan bir evlilik } \\
\text {-Eş, anne ve kayınvalide arasında çatışmalar sonrası başlayan somatik } \\
\text { belirtiler } \\
\text {-Eşinin } 20 \text { gün süren ilk evliliğinden bir çocuğu var. }\end{array}$ & $\begin{array}{l}\text {-Önceki kuşakta ebeveynler tarafından onaylanmayan evlilik } \\
\text { ve evlilik dışı iliş̧i öyküsü }\end{array}$ \\
\hline $15, \mathrm{~K}$ & $\begin{array}{l}\text {-Erken yaşta evlilik ve uzun süre aldatılma, fiziksel şiddete maruz } \\
\text { kalma öyküsü } \\
\text {-İkinci evliliğinden sonra, eșinin kanser olmasıyla başlayan somatik }\end{array}$ & $\begin{array}{l}\text {-Erken yaşta kayıplar } \\
\text {-Bilinen iki kuşakta boşanma, evlilik sorunları }\end{array}$ \\
\hline
\end{tabular}




\begin{tabular}{|c|c|c|}
\hline & $\begin{array}{l}\text { yakınmalar } \\
\text {-Dört kez doğum sonrası çocuk kaybı }\end{array}$ & \\
\hline $16, \mathrm{~K}$ & $\begin{array}{l}\text {-Baba tarafindan fiziksel şiddet, } \\
\text {-Annesinin baba tarafından aldatılması, } \\
\text {-̇̇ki kardeş kaybı } \\
\text {-Evden ayrıldıktan sonra başlayan somatik belirtiler }\end{array}$ & $\begin{array}{l}\text {-Babanın evlilik dışı ilişkisi } \\
\text {-Fiziksel şiddet }\end{array}$ \\
\hline $17, \mathrm{E}$ & $\begin{array}{l}\text {-̇̇stenmeyen bebek (kuyuya atmak istemişler) } \\
\text {-25 yaşında başlayan somatik yakınmalar } \\
\text {-Aileyi bir arada tutabilmek için gösterilen yoğun çaba }\end{array}$ & $\begin{array}{l}\text {-Anneanne } 25 \text { yaşında iken eşinin Kore savaşına gitmesi, } \\
\text { anne } 25 \text { yaşında üç aylık hamileyken eşi tarafından terk } \\
\text { edilmesi ile hastanın belirtilerinin başladığı yaş } \\
\text {-Doğum, düğün gibi başlangıçlar ve kayıplar sonrası artan } \\
\text { belirtiler }\end{array}$ \\
\hline $18, \mathrm{~K}$ & $\begin{array}{l}\text { Aileden ayrılınca başlayan somatik yakınmalar (terk edilme ve yalnız } \\
\text { kalmaya duyarlılık) }\end{array}$ & $\begin{array}{l}\text { Ailede erken yaş kayıpları ve terk edilmeler mevcut (anne } \\
\text { erken yaşta babasını kaybetmiş, baba } 20 \text { günlükken babası } \\
\text { evi terk etmiş, 40'lı yaşlara kadar onunla görüşmemiş; } \\
\text { anneannenin } 2 \text { ölü doğumu var, babaanne babasını erken } \\
\text { yaşta kaybetmiş). Anne ve teyzede stresle tetiklenen somatik } \\
\text { yakınmalar mevcut. }\end{array}$ \\
\hline $19, \mathrm{E}$ & $\begin{array}{l}\text {-Maddi kayıplar sonrası ortaya çıkan somatik belirtiler, } \\
\text {-Aldatılma } \\
\text {-Eşinin düşük ve yenidoğan kaybı öyküsü } \\
\text {-Babasız büyüme }\end{array}$ & $\begin{array}{l}\text {-Anneannenin erken yaşta ailenin onayı olmadan evlenme ve } \\
\text { gebe iken boşanma öyküsü, } \\
\text {-Hastanın annesinin babası olmadan anneannesi ve dedesi } \\
\text { tarafindan büyütülme öyküsü }\end{array}$ \\
\hline $20, \mathrm{~K}$ & $\begin{array}{l}\text {-Aldatılma şüpheleri sonrası başlayan somatik belirtiler } \\
\text {-Kayınpederine uzun süre bakım verme sonrasında onun kaybı ile } \\
\text { belirtilerde artış }\end{array}$ & $\begin{array}{l}\text {-Üç kuşaktır bilinen aile öyküsündeki erken yaştaki } \\
\text { kayıplar } \\
\text {-Kayıplara duyarlılık ve sebebi bilinmeyen fiziksel belirtiler }\end{array}$ \\
\hline $21, \mathrm{E}$ & $\begin{array}{l}\text {-Çocuk sahibi olamama } \\
\text {-İnfertilite ile ilgili genetik testler yapılırken başlayan somatik } \\
\text { belirtiler }\end{array}$ & $\begin{array}{l}\text {-Geçmiş kuşaklarda bebek ölümleri } \\
\text {-Babanın babasında çok sayıda evlilik } \\
\text {-Babanın dedesini savaştan dönmemesi öyküsü } \\
\text {-Annenin küçük yaşta baba kaybı öyküsü }\end{array}$ \\
\hline $22, \mathrm{~K}$ & $\begin{array}{l}\text {-Babasının kendisi } 40 \text { günlükken vurularak ölümü } \\
\text {-Kendisinin dedesi ve üvey babası tarafından büyütülüp } 14 \text { yaşında } \\
\text { evlendirilmesi } \\
\text {-Kızının benzer yaşlarda kaçarak evlenmesi ile başlayan somatik } \\
\text { belirtiler }\end{array}$ & $\begin{array}{l}\text {-Erken yaşta evlilikler, } \\
\text {-Ailede travmatik kayıplar, aile sırları }\end{array}$ \\
\hline
\end{tabular}

\section{K: kadın, E: erkek}

Örnek olgu sunumu: 34 yaşında, evli, 2 çocuklu, lisans mezunu kadın hasta vücudunda uyuşma, karında rahatsızlık hissi ve ağrı yakınmaları ile başvurdu. İlk yakınmalarının yaklaşık 15 yıl önce ayaklarında ortaya çıkan uyuşma ile başladığı, zamanla uyuşmanın dizlerine, bacaklarına ilerlediği ve karın bölgesine kadar ulaştığ öğrenildi. Çok sayıda nöroloji hekimine başvuran hastaya son olarak abdominal epilepsi tanısı ile antiepileptik ilaçlar verilmişti. Bu tedavilerden kısmen yarar gören hastanın yakınmaları tekrarlayınca bir nöroloji servisinde yatırılarak incelendiği, uyku aktivasyonlu EEG çekildiğ $i$ ve normal olarak değerlendirildiği öğrenildi. Epilepsi tanısı dışlanan hasta psikiyatriye yönlendirilmişti. Hastayla yapılan psikiyatrik görüşme sonrasında BBB ve depresyon tanıları konuldu, essitalopram $10 \mathrm{mg} / \mathrm{g}$ başlandı, yanı sıra aydınlatılmış onam alınarak çalışmaya dahil edildi. Yapılan genosoyogram çalışmasında dikkati çeken noktalar Şekil 1'de sunuldu.
Hastanın yaşamının her döneminde bir aileye ve köklerine aidiyet duygusunun eksikliğini yaşadığı, sevgi ve kabul görmemenin, aile tarafından dışlanmanın ve istenilmeyen kişi olmanın atalarından kendisine aktarıldığ 1 fark edildi (yalnızlık, sahipsizlik, köklerinin olmaması, onların parçası olmama). Buna karşın özellikle annesinden kendisine aktarılan olumlu öğeler olarak mücadeleyi sürdürme, yaşama tutunma ve koruyup kollama olduğu dikkati çekti. Hastanın farkettiği bu duygusal yükler nesnelerle sembolleştirildi, atalarına söylemek istediklerinin ifade edilmesi ve duygudışavurumu desteklendi. Kendisine ait olmayan yüklerin sembolik olarak birakılması ve bedenle ifade bulan duyguların sözelleştirilmesi sağlanmış oldu. Kontrol görüşmelerinde hastanın daha iyi hissettiği, uyuşmalarının olmadığın öğrenildi, duygularını daha rahat ifade edebildiği gözlendi. 
Şekil 1.

Örnek olgunun genososyogram çalışması

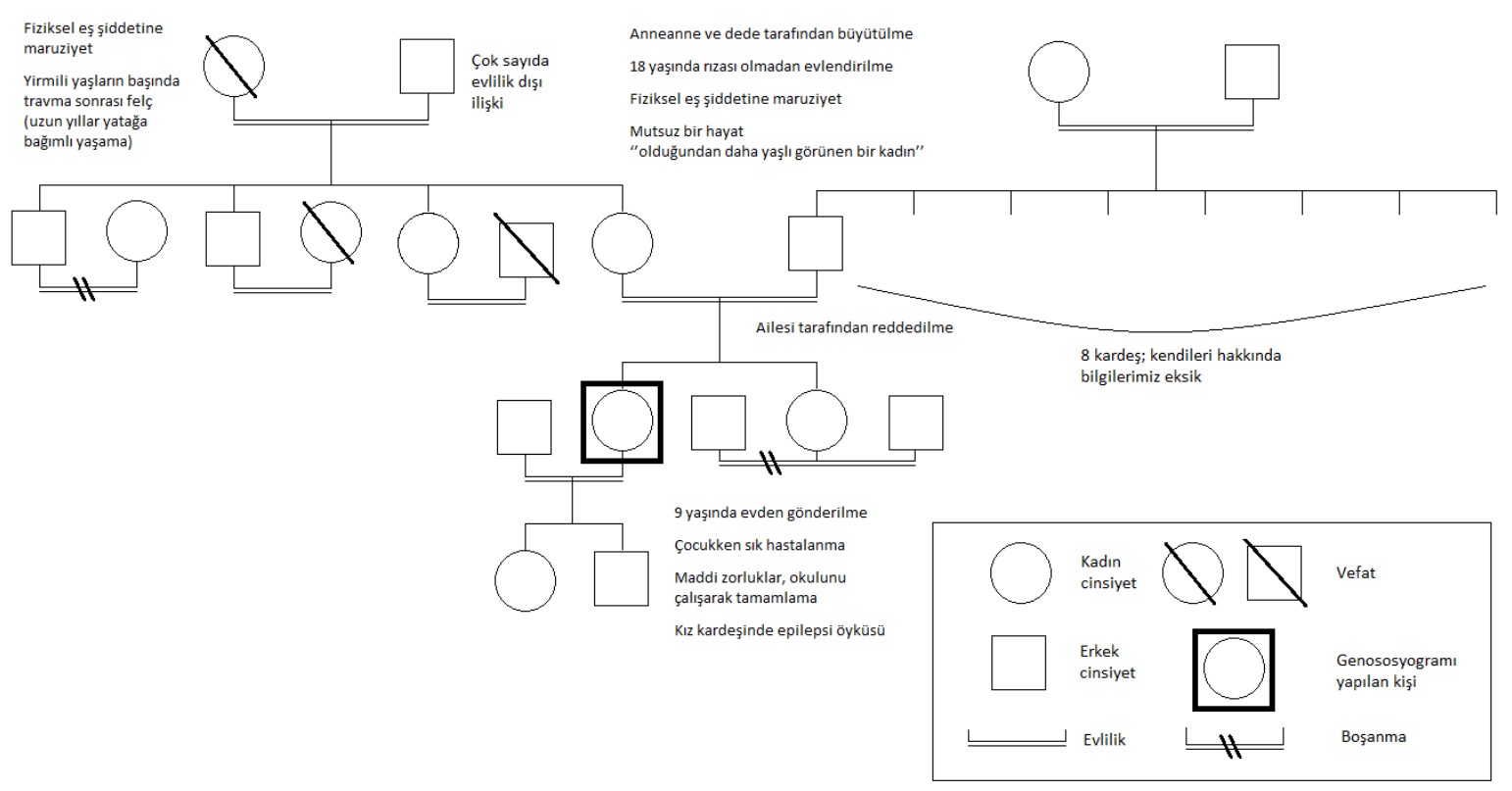

\section{Tartışma}

Hastaların çoğunluğu bedensel belirtiler ile ilişkili olduğu düşünülen psikososyal stres etmenlerine ve çocukluk dönemlerine ait travmatik yaşantılara sahipti. Genososyogramlar incelendiğinde; şiddet maruziyeti, çocukluk döneminde fiziksel hastalık öyküsü, erken yaşta ebeveyn kayıpları, küçük yaşta evlilik, aldatılma, çocuk sahibi olamama, bebek kayıpları, aile içi çatışmalar gibi travmatik kayıpların ve çözümlenmemiş yas süreçlerinin varlığı gözlendi. Kuşaklararası benzer travmatik yaşantıların varlığı ve benzer aile örüntüleri dikkat çekiciydi. Altı hastada $(1,2,3,5,9,18$ numaralı hastalar) kuşaklararası bedensel belirtilerin varlığ 1 , iki hastada (7,17 numaralı hastalar) ise yıldönümü tepkileri belirgin olarak gözlendi.

BBB'de çocukluk çağı travma öyküsünün yüksek olduğu, erken dönem travmatik yaşantıların bu bozukluk açısından nonspesifik risk faktörü olarak önemli rol oynadığ ihmal/istismar ve cinsel istismar ile ilişkili olduğu; yüksek düzeyde bedensel belirtilere sahip hastalarda daha fazla travma öyküsü olduğu belirtilmektedir (Taycan ve ark. 2014; Henker, Keller, Reiss, Croy ve Weidner 2019). Bir meta-analiz çalışmasında, cinsel istismar öyküsü ile fonksiyonel gastrointestinal sendrom, nonspesifik kronik ağrı, non-epileptik nöbet ve kronik pelvik ağrı arasında anlamlı ilişki olduğu bulunmuştur (Paras ve ark. 2009). Bedenselleştirme gelişiminde stresörün varlığ 1 kadar, stres ile baş etme düzeyi de etkili olmaktadır (Wilpart ve ark. 2017). Bizim olgularımızda da psikosoyal stres etmenlerinin ve çocukluk dönemi travmatik yaşantıların yaygın olduğu belirlenmiştir.

Yaşanan her kayıp sonrası şok/şaşkınlık, yadsıma, öfke, korku ve depresyon, hüzün, kabullenme, anlam arayışı ve yenilenme, iç huzurun ve barışın tekrar sağlanması olarak özetlenebilecek bir süreç yaşanmaktadır. Çocukluktaki gereksinimlerin yeterince karşılanmamış olması, erken çocukluk dönemlerinde kayıplar yaşanması, kaybedilen kişiyle aşırı bağımlı ya da bitmemiş meselelerle yüklü bir ilişkinin varlığı, aniden ve kötü bir biçimde karşılaşılan travmatik bir ölüm olması ve kederin dışavurulmasına kısıtlamalar getirilmesi tamamlanmamış yas sürecine yol açabilmektedir (Vamık ve Zintl, 2017). Travmatik bir kayıp sonrası ölümle yüzleşmekten kaçınma ve bu aşamaların birinde saplanma/donma söz konusudur. $\mathrm{Bu}$ kayıpların nesiller arasında aktarım açısından potansiyel risk taşıdığ1 söylenebilir. Olgularımızın çoğunluğunda, hem kendi yaşam öykülerinde hem de aile öykülerinde travmatik kayıpların varlığı göze çarpmaktadır. Bu durum çözümlenmemiş yas süreçlerinin varlığına ve grubumuzun nesiller arası aktarım için risk taşıdığına işaret etmektedir.

Travmanın aktarımına yol açan en önemli şey sessiz kalınmış, sembolize edilmemiş ve bütünleştirilmemiş deneyimlerin varlığıdır. Bu yaşantılar kimi zaman tarihsel ve toplumsal olaylar ile yakın ilişkili olabilmektedir. Kitlesel travmalar ve toplu katliamlardan sonra nesiller arası aktarımın daha çok yaşandığı bilinmektedir. Doğal afetler, savaşlar, katliam veya zorunlu göç gibi yaşantılara maruz kalan gruplar travmayı yeteri kadar işleyemediğinde, travmanın etkileri sonraki nesillerde, grubun kültüründe ve bireylerde ortaya çıkan çeşitli belirtilerle kendini göstermeyi sürdürebilmektedir. Bunlar kültürün oluşumunda önemli etkenler olduğu gibi, kültürün kendisi de bu örtük iletimin sürmesine katk1 sağlayabilmektedir (Schützenberger, 2012; Sengintürk 2019; Sevinç Yalçın ve Öztürk, 2018).

Çocuk ve ebeveyn arasında belli konular, tarihler, isimler, dönüm noktaları söz konusu olduğunda göz temasının kesilmesi veya çeşitli ifadelerle sözel olmayan iletim gerçekleşebilmektedir. Bu iletim üst kuşak tarafindan bilinçli olarak kontrol edilemese de çocuk tarafindan farkedilebilmektedir (Schützenberger, 2012). Çocuğun, diğer kişilerin sözel ileti dışındaki ifadelerini ayırt edebilme becerisiyle ilgili olan zihinselleştirme yetileri burada önemli rol oynamaktadır (Brüne ve Brüne Cohrs, 2006). Zihinselleştirme gelişiminin hangi aşamasında bu 
tür iletilerle karşılaşılmış olduğu, çocuktaki etkileri açısından belirleyici olabilir. Bedenselleştirmenin zihinselleştirme sorunları ve aleksitimi ile ilişkisini gösteren çalışmalar bulunmaktadır (Schönenberg, Mares, Smolka, Zipfel ve Hautzinger, 2014; Ballespi ve ark., 2019).

Çevresel etmenler epigenetik mekanizmalar aracılığıyla DNA dizisinde değişikliğe yol açmadan gen ifadesini değiştirebilmektedir. Bu mekanizmalar gelişim sürecinde gen ekspresyonunu aktive ederek ya da baskılayarak nöroadaptasyon ve hastalık süreçlerinde etkili olmaktadır (Tsankonova, Renthal, Kumar ve Nestler, 2007). Yaşamın erken dönemlerinden itibaren hipotalamohipofizer-adrenal (HPA) eksen her türden fiziksel ve psikolojik kaynaklı stresörler ile tetiklenmekte, glukokortikoidlerin salgılanmasını kontrol ederek stres ve travma karşısında oluşan bir dizi biyolojik yanıtın oluşmasına aracılık etmektedir (Pariante ve Lightman, 2008). Travmaya verilen tepkiler için düzenleyici faktörlerden biri olan glukokortikoid reseptörlerini kodlayan gen (NR3C1) bu nedenle epigenetik çalışmaların önemli hedeflerinden birisi olmuştur. Örneğin bu gendeki DNA metilasyonunun kuşaklararası aktarımını araştıran bir araştırmada; Ruanda katliamından sağ kurtulan kadınlar ve bebeklerinden alınan örneklerdeki NR3C1 geninde, kontrol grubundaki kadınlar ve bebeklerine göre anlamlı olarak daha fazla metilasyon saptanmıştır (Perroud ve ark.,2014). BBB olan hastalarda travma maruziyetinin hem depresyon grubundan hem de sağlıklı kontrol grubundan yüksek olduğu, bu hastalarda aleksitimi düzeylerinin yüksek, zihinselleştirme yetilerinin düşük, aleksitiminin BBB oluşumda yordayıcı olduğu tespit edilmiştir. Duygu düzenleme sisteminde önemli rolü olan HPA eksen işlevlerinde kilit rol oynayan glukokortikoid reseptörlerinde ortaya çıkan epigenetik değişikliklerin duygu tanıma ve ifade süreçlerini etkilediği, söz konusu değişikliklerin erişkin yaşamda ortaya çıkan psikiyatrik bozukluğun etyopatogenezinde rolünün olabileceği bildirilmiştir (Çetin, 2018). Travmatik yaşam olaylarının otonomik sinir sistemi ve endokrin sistem üzerindeki bu etkilerinin hastalığa yatkınlaştırmış olabileceği, epigenetik değişikliklerin ruhsal travmalar ile ilgili etkilerin nesilden nesile aktarılmasının biyolojik açıklamasına önemli katkılar sağlayabileceği söylenebilir.

Bebekler tüm uyaranlara farklılaşmamış bedensel yanıtlarla yanıt vermekte, ego gücünün artmas1, dilin gelișmesiyle olağan emosyonel cevaplar beden dıșı bir duruma doğru ilerlemektedir. Travma veya gelişimdeki ketlenme karşısında olağan uyum konumundan fiziksel temsilin asıl cevap haline geldiği bedensel duruma geri dönüş yaşanmaktadır. Aslında yaşamının başlangıcında tüm insanlar bedenselleştiriciyken, bir takım çevresel etmenler bazı insanların "'bedenselleştiren" olarak kalmasına yol açmaktadır (Ünal, 2002). Örnek olgu incelendiğinde, BBB oluşumu açısından birçok etmenin varlığı göze çarpmaktadır. Çocukluk döneminde travmatik yaşantıların varlığı, fiziksel ve psikolojik şiddete maruz kalma, kardeşinde epilepsi olmas1 dolayısıyla hasta rolünün öğrenilmiş olabileceği ve tüm bu yaşananların duyguların ifade edilmesinde zorluğa yol açtığ1 söylenebilir. Aile öyküsünde, kadınlarda şiddet maruziyetinin en az iki nesildir devam ettiği anlaşılmaktadır. Anneannenin uğradığı şiddet sonucu felç olması ile hastanın benzer yaşlarda başladığı anlaşılan uyuşma yakınmalarının varlığı yıldönümü tepkisini düşündürmektedir.

Genososyogram çalışmasının bir grup ortamında yapılmasının üyelerin etkileşimi ve yaşanmış öykülerle kurulan bağlantıların kolaylaştırıcı olması bakımından daha yararlı olabilir. Ayrıca birden fazla sayıda oturumda çalışılması ailenin diğer üyelerden bilgi alınmasını sağlamakta, fark edilmeyen, görmezden gelinen ve aktarılan duygusal yüklerin gün yüzüne çıkarılmasını kolaylaştırmaktadır (Schützenberger, 2011). Bizim çalışmamızda sadece hasta ile görüşülmüş ve her çalışma tek oturumda tamamlanmıştır. Çalışmamızın BBB olan hastalarda var olan kuşaklararası ve özellikle kuşakaşan bağlantıların ortaya çıarılması, incelenmesi ve hasta üzerinde iyileştirici bir dönüşüm ve değişim sağlamas1 bakımından yeterli olduğunu söylemek güçtür. Ayrıca çalışmamızda nesnel bir ölçüm yöntemi kullanılmamıştır. Bir araştırmada şiddet davranışı olan ergenlerle genososyogram çalışmaları yapılmış ve yarı yapılandırılmış bir görüşme metodu ile istatiksel karşılaştırma daha detaylı olarak uygulanabilmiştir. $\mathrm{Bu}$ modele göre 3 kuşağ 1 kapsayan genososyogram çalışmalarının verileri aile sisteminin yapısı, aile içi roller, aile ile ilgili projeksiyonlar, uyum düzeyi gibi gruplara ayrılarak değerlendirilmiştir (Sitnik-Warchulska ve Izydorczyk, 2018). Bu alan ile ilgili nesnel verilerin oluşturulması için bu tür yapılandırılmış modellerin geliştirilmesi gerekmektedir.

Çalışmamızda "şimdi ve burada" ortaya çıkmış olan duygusal materyal ile psikodramatik yöntemlerle çalışılmış, atalardan aktarılan ve "o anda" fark edilen duygusal yüklerin ayrıştırılması sağlanmıştır. Nitekim yıldönümü etkilerinin anlaşılması ve belirtilerin önceki kuşaktaki başka bir kişiye ait olduğunun farkına varılması, rastlantısal görünen anlamsal bağlantılar ortaya çıkarmakta ve ilişkili belirtiler ortadan kalkabilmektedir. Genososyogram çalışmasının her şeye deva olmadığını ve yararlı olabilmesi için uzun bir psikoterapi sürecinin olması gerektiğini tekrar vurgulamak yerinde olacaktır. Katılımcılar aile içi iletişim yöntemlerinin de etkisiyle önceki kuşakları incitebileceğini, utandırabileceğini hissettiği şeyleri söylemekten geri durabilir. Ya da travmatik geçmişleriyle ilgili gerçekte olandan çok uzak arzu ettikleri, fantezi düzeyindeki anılar ve ilişki biçimlerinin de anlatılmış olması mümkün olabilir (Sitnik-Warchulska ve ark., 2018). Ayrıca bu çalışmaya geçmiş travmatik yaşantı ve/veya aktarılan travmatik yükler açısından riskli olduğunu düşünen bireyler katılmış olabilir. Travmatik yaşantıların tekrarlanmasını sadece soy sendromu ile açıklamak indirgemeci bir yaklaşım olacaktır. Genetik ve epigenetik değişimler, sosyal çevre ve kültürel etmenler ya da bazı öyküler için sadece tesadüfi bir tekrarın söz konusu olabileceği unutulmamalidir.

Sonuç olarak çalışma grubumuzun çoğunluğunda çocukluk dönemi travmatik yaşantılarının olduğu, ailede tekrarlayan travmatik yaşantı ve ilişki örüntülerinin bulunduğu gözlenmiştir. Hastaların yaklaşık üçte birinde benzer bedensel belirti öyküsü ve iki hastada yıldönümü tepkileri belirgin izlenmiştir. BBB olan hastalarda genosoyogram çalışmasının travma ve etkilerinin ayrıntılı olarak incelenmesine ve geçmiş kuşaklardan aktarılan yüklerin fark edilmesine olanak sağladığı söylenebilir. Aynı zamanda atalarımızdan aktarılan güç, umut ve yaşama bağl1lık gibi olumlu öğelerin fark edilmesi ve 
hatırlanması da zorluklarla baş edilmesinde güç verecektir. Geçmişi yok sayarak değil, hatırlayarak ve tamamlayarak kendi yaşamımızı daha özgürce yaşamanın mümkün olduğunu vurgulamak yerinde olacaktır.

\section{Beyannameler}

\section{Etik Onay ve katılım izni}

Pamukkale Üniversitesi Tip Fakültesi Etik Kurul'undan 21.07.2016 tarih ve 60116787-020/44577 sayılı karar yazısiyla etik kurul onayı alınmıştır.

\section{Yayın izni \\ Uygulanamaz.}

\section{Veri ve materyallerin mevcudiyeti \\ Uygulanamaz.}

Çıkar Çatışması

Yazarlar çıkar çatışması olmadığııı beyan eder.

\section{Finansman}

Uygulanamaz.

\section{Yazar Katkıları}

ŞÇ ve GSV kuramsal çerçeveyi oluşturmuş, veri toplamış, toplanan verileri analiz etmiş ve yorumlamıştır. OÖ süpervizyon rolünü üstlenerek makalenin yazılmasında, veri analizinde ve yorumlanmasında katkı sağlamıştır. Tüm yazarlar makalenin son halini okumuş ve onaylamıştır.

\section{Teşekkür}

Uygulanamaz.

\section{Kaynaklar}

American Psychiatric Association, APA (2013). Diagnostic and Statistical Manual of Mental Disorders (5th ed).

Ballespi, S.,Vives, J., Alonso, N., Sharp, C., Ramirez, M.S., Fonagy, P., Barrantes-Vidal, N. (2019). To know or not to know? Mentalization as protection from somatic complaints. PLoSOne 2, 14 (5), e0215308.

Bayraktutan, M., Nalan Kalkan Oğuzhanoğlu, N., Toker-Uğurlu, T. (2020). Sympathetic Skin Response in Social Anxiety Disorder and Its Relationship with Empathy Skills, Alexithymia. Noro Psikiyatr Ars, 57(1), 18-22.

Brüne, M.,Brüne-Cohrs, U. (2006). Theory of mind-evolution, ontogeny, brain mechanisms and psychopathology. Neurosci Bio behav Res, 30, 437-455.

Çetin, Ş. (2018). Bedensel belirti bozukluğu ve major depresyon bozukluğunda çocukluk çağı travmaları, duygu tanıma ve ifadesi ile epigenetik değişiklikler (Yayınlanmamış Uzmanlık Tezi).Pamukkale Üniversitesi Tıp Fakültesi, Psikiyatri Bölümü, Denizli-Türkiye.

Güleç, M.Y., Altintaş, M., İnanç, L., Bezgin, C.H., Koca, E.K., Güleç, H. (2013). Effects of childhood trauma on somatization in major depressive disorder. J Affect Disord, 146 (1), 137-41.

Henker, J., Keller, A., Reiss, N. Croy, I. ve Weidner, K. (2019). Early maladaptive schemas in patients with somatoform disorders and somatization. Clin Psychol Psychother, 26: 418429.

Karadağ, F., Kalkan-Oğuzhanoðlu, N., Özdel, O., Ergin Ş., Kaçar, N. (2010). Psychodrama with psoriasis patients: stressand coping, Anadolu Psikiyatri Dergisi, 11, 220-227.

Paras, M.L., Murad, M.H., Chen, LP. Goranson, E.N. ,Sattler A.L., Colbenson, K.M. Elamin M.B., SeimeR. J., Prokop, LJ., Zirakzadeh, A._(2009). Sexual abuse and lifetime diagnosis of somatic disorders: a systematic review and meta-analysis. JAMA, 302, 550-561.

Pariante, C.M., Lightman, S.L. (2008). The HPA axis in major depression: Classical theories and new developments. Trends Neurosci, 31 (9), 464-8.

Perroud, N., Rutembesa, E., Paoloni-Giacobino, A., Mutabaruka, J., Mutesa, L., Stenz, L. ve ark., (2014). The Tutsi genocide and transgenerational transmission of maternal stress: epigenetics and biology of the HPA axis. World J Biol Psychiatry, 15 (4), 334-45.

Schönenberg M, Mares L, Smolka R., Zipfel S., Hautzinger, M. (2014). Facial affect perception and mentalizing abilities in female patients with persistent somatoform pain disorder. Eur $J$ Pain, 18, 949-56.
Sengintürk, P. (2019). Travmanın nesiller arası aktarımı: Patrick Modiano ve post-bellek. Turkish Studies Language and Literature, 14 (3), 1547-1559.

Sevinç Yalçın, Ç.P. ve Öztürk E. (2018). Travma sonrası zamanın donması ve travmanın nesiller arası aktarımı. Bartın Üniversitesi Edebiyat Fakültesi Dergisi, 3 (3), 21-28.

Sitnik-Warchulska, K., ve Bernadetta Izydorczyk, B. (2018). Family Patterns and Suicidal and Violent Behavior among Adolescent Girls-Genogram Analysis. Int. J. Environ. Res. Public Health, 15, 2067.

Schützenberger, A.A. (2011). Soy sendromu (Kuşakaşanterapi ve soyağacındaki gizli bağlantılar). (İ. Doğaner Çev.). İzmir: Duvar Yayınları.

Schützenberger, A.A. (2012). Psikosoybilim. (K. Kahveci Çev). İstanbul: Türkiye İş Bankası Kültür Yayınları.

Sözeri-Varma, G., Karadağ, F., Kalkan-Oğuzhanoğlu, N., Özdel, O. (2017). Depresyon tedavisinde grup psikoterapisi ve psikodramanın yeri. Klinik Psikiyatri Dergisi, 20 (4), 308-317.

Taycan, O., Sar, V., Celik, C., Erdoğan Taycan, S. (2014). Trauma-related psychiatric comorbidity of somatization disorder among women in eastern Turkey. Compr Psychiatry, 55: 18371846.

Tsankova, N.,Renthal, W., Kumar, A., Nestler, E.J. (2007) Epigenetic regulation in psychiatric disorders. Nat Rev Neurosci, 8, 355-67.

Ünal, S. (2002). Bir anlatım tarzı olarak bedenselleştirme. Anadolu Psikiyatri Dergisi, 3(1), 52-55.

Volkan, V. ve Zintl, E. (2017). Kayıptan sonra yaşam, Ankara: Pusula Yayınevi.

Wilpart, K.,Törnblom, H., Svedlund, J., Tack, J.F., Simrén, M., Van Oudenhove, L. (2017). Coping skills are associated with gastrointestinal symptom severity and somatization in patients with irritable bowel syndrome. Clin Gastroenterol Hepatol, 15 (10), 1565-1571.

Wolynn, M. (2016). Seninle Başlamadı. (M. Madenoğlu Çev.) İstanbul: Sola Yayınları. 